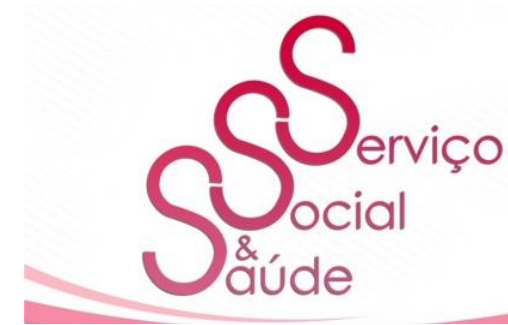

ISSN 2446-5992

(ब) 100

doi: $10.20396 /$ sss.v18i0.8656802

\title{
Debate sobre juventudes, violência e invisibilidade
}

\section{Debate about youth, violence, and invisibility}

\section{Daniel Péricles Arruda ${ }^{1}$}

\section{RESUMO}

O debate sobre as juventudes é uma questão emergente e importante para tornar conhecidos os modos de vida e as demandas desses sujeitos. O objetivo deste artigo é refletir sobre alguns aspectos das relações entre as juventudes com os processos de formação da violência e invisibilidade. A partir do apoio teórico interdisciplinar e da metodologia qualitativa para a análise de documentos, de dados estatísticos e experiência profissional, observa-se a importância de investimento em políticas públicas que reconheçam as singularidades e diversidades desse público e da elaboração de estratégias de aproximação e leitura das expressões juvenis.

PALAVRAS-CHAVE: Invisibilidade. Juventudes. Relações étnico-raciais. Violência.

\begin{abstract}
The debate about youth is an evolving and important issue to shed light on their ways of life and the demands they are subjected. The objective of this article is to reflect on some aspects of the relationship between young people and the formation processes of violence and invisibility. With interdisciplinary theoretical support and employing qualitative methodology to analyze documents, statistical data, and professional experience, we can grasp the importance of investing in public policies that recognize the distinctiveness and diversity of this population and the formulation of strategies to approach and interpret youthful expressions.
\end{abstract}

KEYWORDS: Invisibility. Youth. Ethnic-racial relations. Violence.

\footnotetext{
${ }^{1}$ Professor do Curso de Serviço Social da UNIFESP, Campus Baixada Santista. Graduado em Serviço Social pela PUC Minas; Mestre - bolsista do Ford Foundation International Fellowships Program (Turma 2010) - e Doutor em Serviço Social pela PUC-SP; Pós-Doutor em Psicologia Social pela PUC-SP; formando em Psicanálise pelo Instituto Langage. É rapper e poeta conhecido como Vulgo Elemento. Site: http://www.vulgoelemento.com.br/ Telefone: 5513 3229-0100. E-mail: pericles.daniel@ unifesp.br.
}

\begin{tabular}{|l|c|c|c|c|c|c|c|}
\hline Serv. Soc. \& Saúde & Campinas, SP & \multicolumn{2}{|c|}{ v. 18} & $1-22$ & e019001 & 2019 & e-ISSN 2446-5992 \\
\hline Serv. Soc. \& Saúde & Campinas, SP & v. 18 & \multicolumn{2}{|c|}{$1-22$} & e019001 & 2019 & e-ISSN 2446-5992 \\
\hline Serv. Soc. \& Saúde & Campinas, SP & v. 18 & n. 1 [27] & p.9-30 & jan./jun. 2019 & e-ISSN 2446-5992 \\
\hline
\end{tabular}




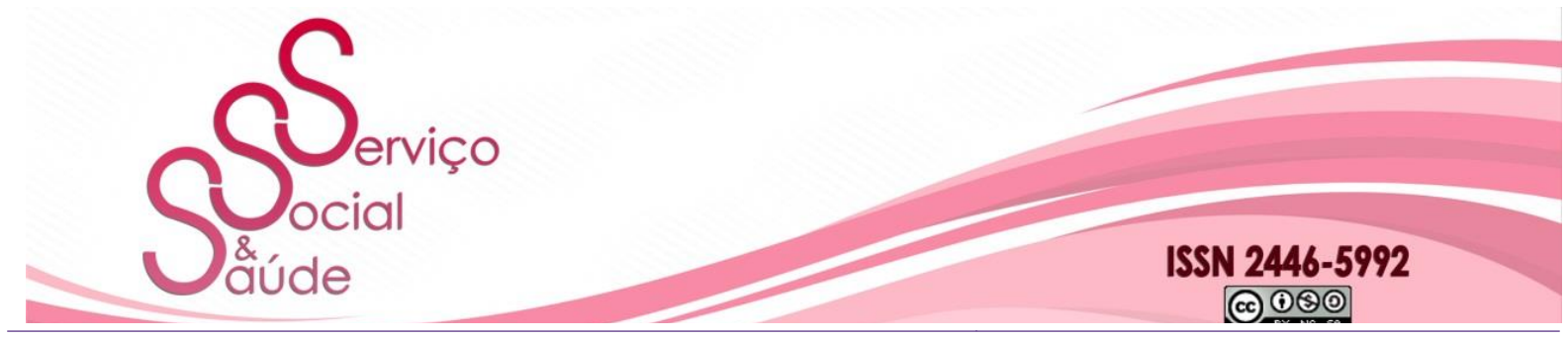

doi: $10.20396 /$ sss.v18i0.8656802

\section{INTRODUÇÃO}

É relevante considerar que a juventude brasileira, na atualidade, tem se manifestado no "mundo", na vida cotidiana, de modo diverso, criativo, intenso e contraditório. Essa juventude cria e recria o seu próprio modo de vida. Mostra que a sua constituição não se faz sem singularidade e que a sua formação é constituída de pluralidades. Isso porque:

O homem - por mais que seja, por isso, um indivíduo particular, e precisamente sua particularidade faz dele um indivíduo e uma coletividade efetivo-individual (wirkliches individuelles Gemeinwesen) - é, do mesmo modo, tanto a totalidade, a totalidade ideal, a existência subjetiva da sociedade pensada e sentida para si, assim como ele também é na afetividade, tanto como intuição e fruição efetiva da existência social, quanto como uma totalidade de externação humana de vida (MARX, 2004, p. 108).

Nessa totalidade formada por diversas totalidades, o/a jovem precisa "anti-padronizarse" para ser diferente. Ao mesmo tempo, precisa "assemelhar-se", para ser aceito/a e reconhecido/a. O/A jovem chega a um "mundo" que está em desenvolvimento e repleto de adultos que acreditam dominar a totalidade dos conhecimentos e, por esse motivo, acreditam ter o direito de dizer o que é correto e como o/a jovem deve viver. Mas o/a jovem tem necessidades que são comuns aos demais sujeitos, enquanto outras lhe são singulares.

Por outro lado, muitos adultos se esquecem de que cada jovem tem o seu "mundo próprio", composto de desejos, conflitos, medos, suas angústias e expectativas. E nessa relação entre os "mundos", ou dimensões subjetivas e vida cotidiana, é que se constroem os processos de identidade decorrentes do momento social, histórico e cultural.

A juventude, como toda categoria socialmente constituída, que atende a fenômenos existentes, possui uma dimensão simbólica, mas também tem que ser analisada a partir de outras dimensões: aspectos fáticos, materiais, históricos e políticos, nos quais toda produção social se desenvolve (MARGULIS apud ABRAMO, 2005, p. 42).

O conceito de juventude é oriundo, principalmente, das relações e concepções sociais comuns em determinada cultura. Ao observar as expressões juvenis, é possível identificar as peculiaridades desse grupo; como se apresenta, como é visto socialmente e como se vê

\begin{tabular}{|l|c|c|c|c|c|c|c|}
\hline Serv. Soc. \& Saúde & Campinas, SP & v. 18 & $1-22$ & e019001 & 2019 & e-ISSN 2446-5992 \\
\hline Serv. Soc. \& Saúde & Campinas, SP & v. 18 & $1-22$ & e019001 & 2019 & e-ISSN 2446-5992 \\
\hline Serv. Soc. \& Saúde & Campinas, SP & v. 18 & n. $1[27]$ & p.9-30 & jan./jun. 2019 & e-ISSN 2446-5992 \\
\hline
\end{tabular}




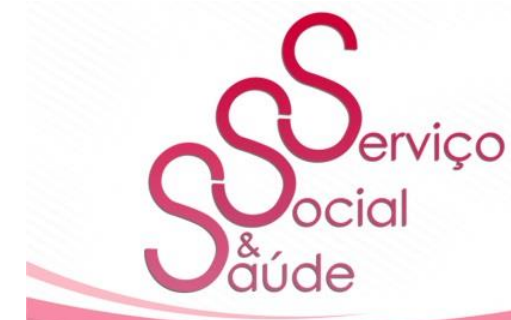

ISSN 2446-5992

(๑) $\odot$ (-)

doi: $10.20396 /$ sss.v18i0.8656802

3

historicamente e no tempo presente. Abramo (2005) analisa a condição - ou seja, a forma como a sociedade elabora o significado desse ciclo da vida -, e a situação - a forma da vivência a partir de algumas classificações, por exemplo, de classe, gênero, raça/cor. A condição e situação da juventude sinalizam para a reflexão de juventudes, no plural, para marcar a posição das desigualdades e diferenças que caracterizam esses sujeitos.

No Brasil, numa perspectiva universal, a juventude envolve uma totalidade constituída por especificidades que demandam atenção, assim como a educação, renda, religião; dinâmica e constituição familiar; relação/identidade de gênero, diversidade sexual; condição de habitabilidade e territorial, etc. A juventude brasileira, portanto, constitui um "mosaico cultural”, em razão das várias juventudes em desenvolvimento no País.

Apesar de existirem legislações específicas, por exemplo, o Estatuto da Juventude ${ }^{2}$, a produção e a reprodução da juventude brasileira demanda atenção para ouvi-la e entendê-la a partir de seus valores e da sua realidade. No caso brasileiro, a desigualdade social entre as pessoas, em especial as juventudes, é imensa. Numa sociedade que está sob a égide do modo de produção capitalista, sabe-se perfeitamente qual é o tipo médio de jovem que, geralmente, tem mais dificuldade para acessar os direitos sociais, como cidadão de fato, e o que faz parte de relações permeadas pela violência: o jovem que é negro, pobre, periférico, com idades entre 15 e 29 anos e de baixa escolaridade, como demostram os últimos Mapas e Atlas da Violência no Brasil.

A violência não é exclusividade da juventude de determinada classe social e/ou grupo étnico-racial, porém, conforme a sua estética, localização e o seu posicionamento social, de acordo com Soares (2011), identifica-se o tratamento desigual na relação com as instituições pertencentes à Segurança Pública e à Justiça Criminal. Quer dizer, “A lei afirma que todos são iguais, mas, na prática, alguns são mais iguais do que outros. Os direitos de alguns são

\footnotetext{
${ }^{2}$ Lei n. 12.852, de 5 de agosto de 2013, que considera, em seu artigo 1으, § 1ㅇ, que: "Para os efeitos desta Lei são considerados jovens as pessoas com idade entre 15 (quinze) e 29 (vinte e nove) anos". E no $§ 2^{\circ}$ (do mesmo artigo) traz: "Aos adolescentes com idade entre 15 (quinze) e 18 (dezoito) anos aplica-se a Lei n. 8.069, de 13 de julho de 1990 - Estatuto da Criança e do Adolescente, e, excepcionalmente, este Estatuto, quando não conflitar com as normas de proteção integral do adolescente".
}

\begin{tabular}{|l|c|c|c|c|c|c|c|c|}
\hline Serv. Soc. \& Saúde & \multicolumn{2}{|c|}{ Campinas, SP } & \multicolumn{2}{c|}{ v. 18} & $1-22$ & e019001 & 2019 & e-ISSN 2446-5992 \\
\hline Serv. Soc. \& Saúde & Campinas, SP & v. 18 & \multicolumn{1}{|c|}{$1-22$} & e019001 & 2019 & e-ISSN 2446-5992 \\
\hline Serv. Soc. \& Saúde & Campinas, SP & v. 18 & n. $1[27]$ & p.9-30 & jan./jun. 2019 & e-ISSN 2446-5992 \\
\hline
\end{tabular}




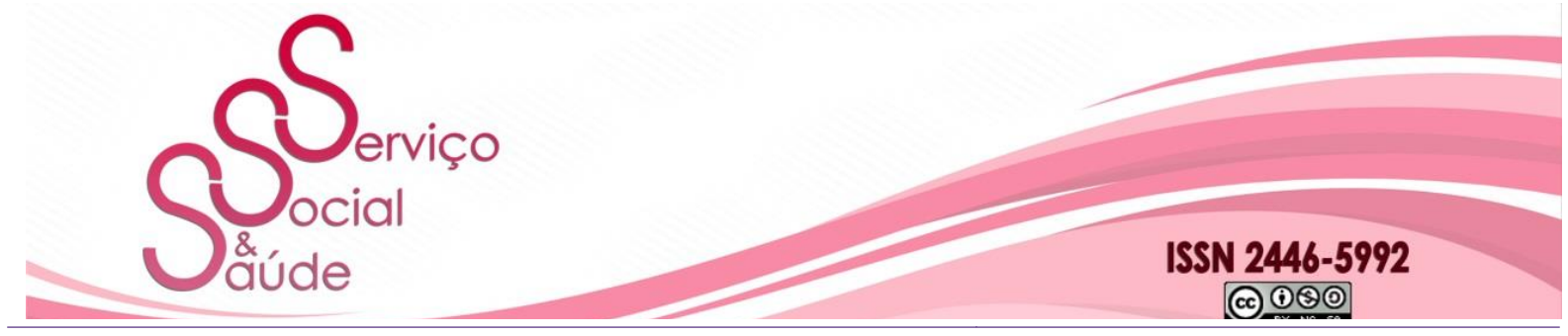

doi: $10.20396 /$ sss.v18i0.8656802

garantidos com muito mais atenção, rapidez e eficácia do que outros” (SOARES, 2011, p. 89).

O debate sobre violência é complexo, embora, na visão imediata, a sua expressão física seja mais percebida socialmente. Porém, nota-se que são vastos os processos de construção da violência que, inclusive, podem se expressar de modo psicológico, sexual, patrimonial, moral, simbólico, institucional, etc. Uma violência pode produzir outra, e estar articulada a várias outras. Importante considerar que nenhuma manifestação da violência traz em si uma explicação definida. Assim, a sua interpretação pode apresentar elementos que ampliam a compreensão daquilo que está escondido e/ou que se apresenta por meio da violência.

Soares et al. (2005, p. 237) pondera que "a violência se aprende, como se aprende a praticar e orientar-se para a paz". Para o autor, o ser humano, ser de aprendizagem e culturalização, não nasce definido e nem segue um único caminho em sua trajetória. Portanto, a violência, assim como a paz, tem como uma de suas medições o aprendizado.

Chaui (2017) considera que, além de conceituar a violência, é preciso saber como ocorre a sua operação nos vários contextos. A autora chama a atenção para aquela violência sutil, que não é menos perversa, porém, nem sempre, é percebida. A amplificação do que se pensa sobre a violência, supera a sua associação com a violência física e a criminalidade, demonstrando a relação da violência com o poder.

Para Adorno e Nery (2019, p. 171-172), a "Violência tem sentido polissêmico, pois depende dos valores considerados 'sagrados' em uma sociedade em momento determinado de sua história". Violência, então, baseia-se nos valores referenciais estabelecidos como importantes para a coletividade, no tempo e espaço da convivência social.

No caso da juventude, o estudo intitulado Prevenindo a Violência Juvenil: um panorama das evidências, publicado em 2015 pela Organização Mundial da Saúde (OMS) e pelo Núcleo de Estudos da Violência da Universidade de São Paulo, apresenta diversas modalidades de violência, reflexões, fatores de risco e estratégias voltadas para a prevenção.

Assim, este artigo apoia-se nas conceituações apresentadas pelos/as autores/as,

\begin{tabular}{|l|c|c|c|c|c|c|c|}
\hline Serv. Soc. \& Saúde & Campinas, SP & v. 18 & $1-22$ & e019001 & 2019 & e-ISSN 2446-5992 \\
\hline Serv. Soc. \& Saúde & Campinas, SP & v. 18 & $1-22$ & e019001 & 2019 & e-ISSN 2446-5992 \\
\hline Serv. Soc. \& Saúde & Campinas, SP & v. 18 & n. $1[27]$ & p.9-30 & jan./jun. 2019 & e-ISSN 2446-5992 \\
\hline
\end{tabular}




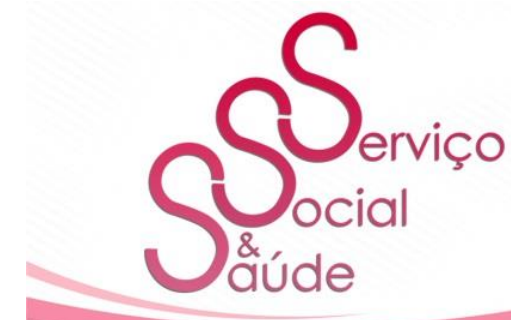

ISSN $2446-5992$

(๑) $\odot \odot$

doi: $10.20396 /$ sss.v18i0.8656802

considerando ser violência, inclusive, qualquer ação individual, grupal e/ou institucional, que impeça a efetivação, ou que viole algum dos direitos especificados na Declaração Universal dos Direitos Humanos (1948).

Pensando a realidade brasileira a partir do elevado índice de homicídios da população jovem, Gomes e Laborne (2018), ao enfatizar o estudo da juventude negra, afirmam que a violência contra essa população, como uma prática racista, ocorre principalmente pela própria condição de raça.

O estereótipo do suspeito número um e a imagem que amedronta a classe média é: o jovem negro da favela com alguma coisa na mão que sempre será interpretada pela polícia como arma ou droga, mesmo que seja somente um saquinho de pipoca. Como me disse um jovem negro militante: "No Brasil, a cor do medo é negra!" (GOMES; LABORNE, 2018, p. 4).

Mas o que há por trás desses traços que, muitas vezes, camuflam a condição do sujeito? Sabe-se que a taxa de homicídios que envolvem jovens com essas características é elevada. Mas o que não se sabe, ainda, para superar essa questão? Ou o que se sabe, mas não está efetivamente funcionando para resolver o problema?

Percebe-se que a violência é uma forma de produção e apresentação da invisibilidade que acomete muitos/as jovens na sociedade. Pois a invisibilidade, conforme Soares et al. (2005), é construída pelo preconceito, estigma, pela indiferença, e falta de reconhecimento humano.

Uma das formas mais eficientes de tornar alguém invisível é projetar sobre ele ou ela um estigma, um preconceito. Quando o fazemos, anulamos a pessoa e só vemos o reflexo de nossa própria intolerância. Tudo aquilo que distingue a pessoa, tornando-a um indivíduo; tudo o que nela é singular desaparece. O estigma dissolve a identidade do outro e a substitui pelo retrato estereotipado e a classificação que lhe impomos (SOARES et al., 2005, p. 175).

Portanto, sem pretensões de exaurir o tema proposto, neste artigo visa-se debater e apresentar algumas reflexões sobre juventudes, violência e invisibilidade, a partir dos últimos dados estatísticos divulgados, de análises sobre a influência da mídia e de casos oriundos de acompanhamento técnico para refletir a respeito do assunto. Antes disso, faz-se necessário

\begin{tabular}{|l|c|c|c|c|c|c|c|}
\hline Serv. Soc. \& Saúde & Campinas, SP & \multicolumn{2}{|c|}{ v. 18} & $1-22$ & e019001 & 2019 & e-ISSN 2446-5992 \\
\hline Serv. Soc. \& Saúde & Campinas, SP & v. 18 & \multicolumn{1}{|c|}{$1-22$} & e019001 & 2019 & e-ISSN 2446-5992 \\
\hline Serv. Soc. \& Saúde & Campinas, SP & v. 18 & n. $1[27]$ & p.9-30 & jan./jun. 2019 & e-ISSN 2446-5992 \\
\hline
\end{tabular}




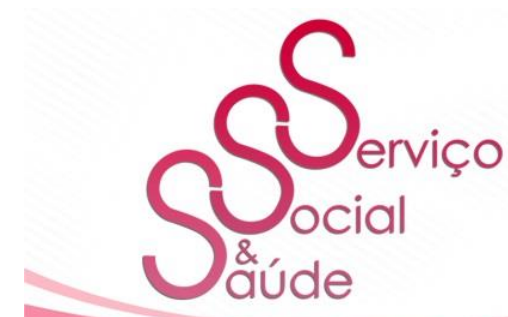

ISSN 2446-5992

(1)(0)

doi: 10.20396/sss.v18i0.8656802

6

apresentar os caminhos de pesquisa percorridos.

\section{PROCEDIMENTOS METODOLÓGICOS}

Chizzotti (2010, p. 79) considera que a pesquisa qualitativa “[...] parte do fundamento de que há uma relação dinâmica entre o mundo real e o sujeito, uma interdependência viva entre o sujeito e o objeto, um vínculo indissociável entre o mundo objetivo e a subjetividade do sujeito".

Nessa concepção, no estudo realizado, atentou-se para as manifestações objetivas e subjetivas que envolvem o tema em questão. Para isso, foi fundamental a análise do diário de campo utilizado durante a atuação profissional do pesquisador com jovens em cumprimento de medida socioeducativa de internação e o levantamento de documentos oficiais que apresentam os dados estatísticos sobre a violência no Brasil, com foco na juventude. São documentos que contemplam "toda informação sistemática, comunicada de forma oral, escrita, visual ou gestual, fixada em um suporte material, como fonte durável de comunicação" (CHIZZOTTI, 2010, p. 109).

Para discutir como os/as jovens aparecem na mídia, apresentam-se reflexões a partir das contribuições de Sales (2007), Soares et al (2005) e Soares 2011; por fim, em outra perspectiva geracional, foram escolhidos três casos de adolescentes/jovens que cumpriram medida socioeducativa para examinar a relação desses sujeitos com o ato infracional.

\section{O QUE DIZEM AS ESTATÍSTICAS SOBRE A VIOLÊNCIA, NO BRASIL?}

Os dados estatísticos demonstram como os/as jovens são acometidos/as pela violência de acordo com a região, raça/cor, faixa etária, sexo, entre outros aspectos. Detalhe pertinente é observar que esses dados seguem uma linha evolutiva de crescimento.

O Mapa da Violência de 2014 - Os Jovens do Brasil - revela que:

[...] os homicídios são hoje a principal causa de morte de jovens de 15 a 29 anos no Brasil, e atingem especialmente jovens negros do sexo masculino, moradores das periferias e áreas metropolitanas dos centros urbanos. Dados

\begin{tabular}{|l|c|c|c|c|c|c|c|c|}
\hline Serv. Soc. \& Saúde & Campinas, SP & v. 18 & $1-22$ & e019001 & 2019 & e-ISSN 2446-5992 \\
\hline Serv. Soc. \& Saúde & Campinas, SP & v. 18 & \multicolumn{1}{|c|}{$1-22$} & e019001 & 2019 & e-ISSN 2446-5992 \\
\hline Serv. Soc. \& Saúde & Campinas, SP & v. 18 & n. $1[27]$ & p.9-30 & jan./jun. 2019 & e-ISSN 2446-5992 \\
\hline
\end{tabular}




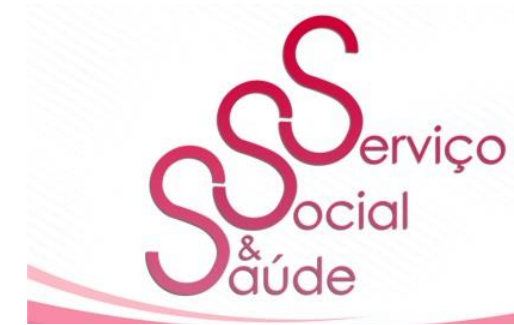

ISSN 2446-5992

(๑) $\odot \odot$

doi: $10.20396 /$ sss.v18i0.8656802

do SIM/DATASUS do Ministério da Saúde mostram que mais da metade dos 56.337 mortos por homicídios, em 2012, no Brasil, eram jovens (30.072, equivalente a $53,37 \%$ ), dos quais $77,0 \%$ negros (pretos e pardos) e $93,30 \%$ do sexo masculino (WAISELFISZ, 2014, p. 9).

No Mapa da Violência de 2015 - Mortes Matadas por Armas de Fogo (Dados analisados do período de 1980 a 2012) -, identificam-se dados alarmantes. De 1980 a 2012, morreram, no País, 880.386 pessoas vítimas de disparo de arma de fogo. Desse total, 497.570 $(56,5 \%)$ eram jovens com idades entre 15 e 29 anos.

Nesse mapa, a taxa de óbitos no Brasil (em 100 mil habitantes) por arma de fogo, da população jovem, é de 47,6. Entre as Unidades Federadas, Roraima (12,2), Santa Catarina $(17,8)$ e São Paulo $(19,3)$ têm as menores taxas. E Ceará $(82,9)$, Espírito Santo $(91,8)$ e Alagoas (123,6), as maiores.

Em 2012, foram vítimas de arma de fogo, no Brasil, 42.416 pessoas, o que representa 116 óbitos por dia. Esses dados chegam a ser superiores a outros países que convivem em estado de guerra formalmente declarada. Desse modo, o caso brasileiro exige que os dados sejam analisados com base na diversidade étnico-racial, nos aspectos sócio-históricos, nas especificidades territoriais e culturais de cada região, nos atos infracionais e/ou crimes cometidos pelos/as jovens e nas ações desumanas do Estado. Outra questão a ser considerada é o fácil acesso às armas de fogo e às munições que se têm no País, bem como sua entrada no território nacional, mesmo com o Estatuto do Desarmamento (Lei n. 10.826/2003).

A taxa de óbitos por arma de fogo (em 100 mil habitantes - população total) no País é de $21,9^{3}$. Em razão disso, ocupa o $11^{\circ}$ lugar entre 90 países pesquisados sobre homicídios ocorridos por esse meio. O Brasil está atrás da Venezuela, das Ilhas Virgens (EUA), de El Salvador, Trinidad e Tobago, Guatemala, Colômbia, Iraque, Bahamas, Belize e Puerto Rico.

Nas Unidades Federadas, as taxas de óbito por arma de fogo são as seguintes: nas últimas posições com as menores taxas, estão: São Paulo, 10,1; Santa Catarina, 8,6; e

\footnotetext{
${ }^{3}$ De acordo com o Mapa da Violência de 2015, analisando apenas os homicídios, em 2012, a taxa é de 20,7 por 100 mil habitantes - população total.
}

\begin{tabular}{|l|c|c|c|c|c|c|c|c|}
\hline Serv. Soc. \& Saúde & Campinas, SP & v. 18 & $1-22$ & e019001 & 2019 & e-ISSN 2446-5992 \\
\hline Serv. Soc. \& Saúde & Campinas, SP & v. 18 & $1-22$ & e019001 & 2019 & e-ISSN 2446-5992 \\
\hline Serv. Soc. \& Saúde & Campinas, SP & v. 18 & n. $1[27]$ & p.9-30 & jan./jun. 2019 & e-ISSN 2446-5992 \\
\hline
\end{tabular}




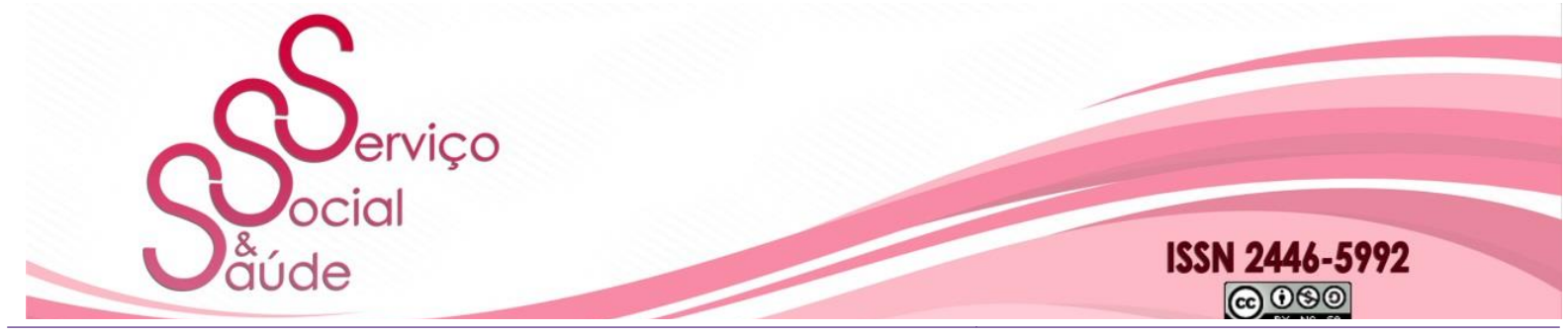

doi: $10.20396 /$ sss.v18i0.8656802

8

Roraima, 7,5. E nas três primeiras posições com as maiores taxas, estão: Alagoas, 55,0; Espírito Santo, 38,3; e Ceará, 36,7. Das 27 Unidades Federadas, apenas 11 apresentam taxas inferiores às do País, que é de 21,9.

O Mapa da Violência de 2015 também confirma que as armas de fogo são as mais utilizadas nas principais causas de mortalidade da juventude no Brasil. E que as taxas são elevadas e vêm aumentando entre os jovens negros.

Já o Mapa da Violência de 2016 (homicídios por armas de fogo no Brasil) ${ }^{4}$, aponta que, entre 1980 e 2014, morreram no País, vítimas de disparo de arma de fogo, 967.851 pessoas. "Nesse período, as vítimas passam de 8.710, no ano de 1980, para 44.861, em 2014, o que representa um crescimento de 415,1\%" (WAISELFISZ, 2016, p. 15).

De 1980 a 2003, o aumento dos homicídios por arma de fogo foi constante e sistemático, com índices em crescimento de $8,1 \%$ ao ano. A partir de 2003, observa-se o crescimento anual de 2,2\%, considerando as oscilações. Provavelmente, um dos motivos dessa queda deve-se às políticas de desarmamento. Nas Unidades Federadas, as taxas de homicídios por arma de fogo (em 100 mil habitantes - população total) são as seguintes: nas últimas posições com as menores taxas, estão: Roraima, com 9,5; São Paulo, com 8,2; Santa Catarina, com 7,5. Nas três primeiras posições com as maiores taxas, estão: Alagoas, com 56,1; Ceará, com 42,9; e, Sergipe, com 41,2. Das 27 Unidades Federadas, apenas 12 estão com taxas inferiores às do País, que é de 21,2 .

Predominam as vítimas masculinas de arma de fogo, com 94,4\% de média nacional. Há significativa homogeneidade desse aspecto, no que se refere aos estados e às regiões do País. Isto é, a variação é de $91 \%$ a $96 \%$ de vítimas do sexo masculino.

Em relação à idade das vítimas, a juventude entre 15 e 29 anos tem sobressaído. Em 1980, foram 6.104 vítimas no total, dessas, 3.159 (51,8\%) eram jovens. Em 2014, das 42.291 vítimas, no total, 25.255 (59,7\%) eram jovens.

${ }^{4}$ Waiselfisz (2016) afirma que os dados de 2014 são preliminares.

\begin{tabular}{|l|c|c|c|c|c|c|c|c|}
\hline Serv. Soc. \& Saúde & Campinas, SP & \multicolumn{2}{|c|}{ v. 18} & $1-22$ & e019001 & 2019 & e-ISSN 2446-5992 \\
\hline Serv. Soc. \& Saúde & Campinas, SP & v. 18 & 18 & $1-22$ & e019001 & 2019 & e-ISSN 2446-5992 \\
\hline Serv. Soc. \& Saúde & Campinas, SP & v. 18 & n. 1 [27] & p.9-30 & jan./jun. 2019 & e-ISSN 2446-5992 \\
\hline
\end{tabular}




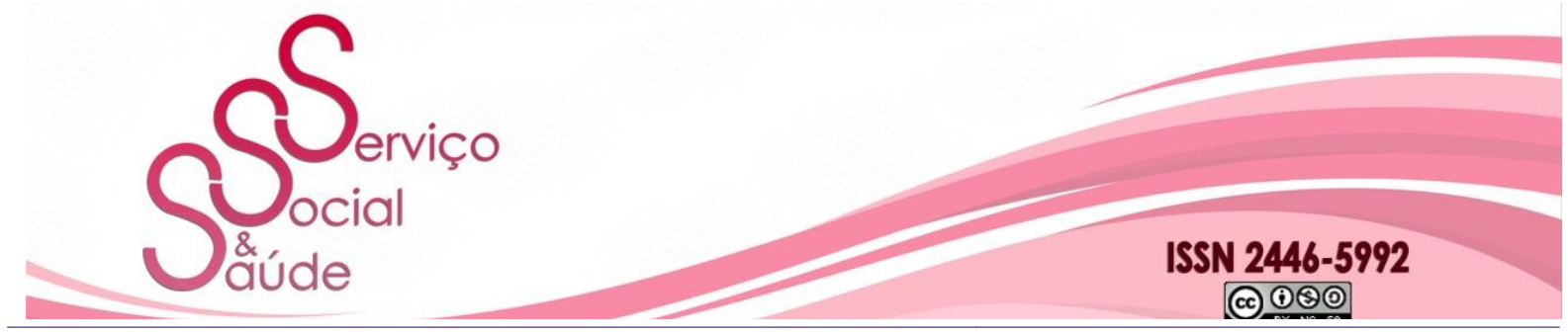

doi: $10.20396 /$ sss.v18i0.8656802

A partir dos 12/13 anos de idade é que se evidencia a escalada acentuada dos homicídios por arma de fogo, com maior concentração de mortalidades na idade de 20 anos, momento em que os homicídios por arma de fogo alcançam a taxa de 67,4 mortes por 100 mil jovens.

Com foco na população com idades entre 15 e 29 anos, o Mapa da Violência - 2016 traz que a média do País, em relação à taxa de homicídios por arma de fogo (por 100 mil), é de 51,6. Entre as Unidades Federadas, Roraima (15,5), Santa Catarina $(16,6)$ e São Paulo $(18,1)$ têm as menores taxas. E Sergipe $(95,8)$, Ceará $(108,1)$ e Alagoas $(124,0)$, as maiores.

Quanto à cor das vítimas, em três estados brasileiros matam-se mais brancos do que negros: Tocantins, Acre e Paraná. Entretanto, em Alagoas, em 2014, foram registrados 1.702 assassinatos de pessoas negras e 60 de brancas.

O Brasil, com a taxa de $20,7^{5}$ de homicídios por arma de fogo (por 100 mil habitantes), está na $10^{\mathrm{a}}$ posição, entre 100 países pesquisados. O País está atrás de Honduras, El Salvador, Ilhas Virgens (EUA), Venezuela, Colômbia, Bahamas, Belize, Porto Rico e Guatemala. As taxas do Brasil chegam a ser 207 vezes mais do que a Dinamarca, Espanha, Alemanha, Polônia e Áustria, dentre outros países que registram a taxa de 0,1 homicídios com arma de fogo por 100 mil habitantes. A taxa do Brasil chega a ser maior (103 vezes) do que a Suécia, França, o Egito e Cuba, dentre vários outros, com taxa por volta de 0,2 homicídios por arma de fogo por 100 mil habitantes.

Documento que requer atenção, o Atlas da Violência de 2017 aponta que, em 2015, houve 59.080 homicídios no Brasil. O que corresponde à taxa de 28,9 por 100 mil habitantes. Dessas mortes, 31.264 foram de jovens com idades entre 15 e 29 anos.

De modo geral, de cada 100 pessoas assassinadas no Brasil, 71 são negras. O estudo aponta - na mesma abordagem dos Mapas da Violência -, que o perfil típico das vítimas fatais continua o mesmo: jovens, do sexo masculino, negros, com baixa escolaridade. Questão considerada pelos estudos é que a violência contra esses jovens vem aumentando cada vez

${ }^{5}$ O levantamento considerou a taxa de 2012.

\begin{tabular}{|c|c|c|c|c|c|c|c|}
\hline Serv. Soc. & Campinas, SP & V. 1 & & $\mathrm{e} 01$ & \multicolumn{2}{|c|}{2019} & 2446 \\
\hline Serv. Soc. \& Saúde & Campinas, SP & v. 18 & $1-22$ & e019001 & 2019 & \multicolumn{2}{|r|}{ SSN 2446-5992 } \\
\hline Serv. Soc. \& Saúde & Campinas, SP & v. 1 & n. 1 & p.9-30 & & & 019 e-ISSN \\
\hline
\end{tabular}




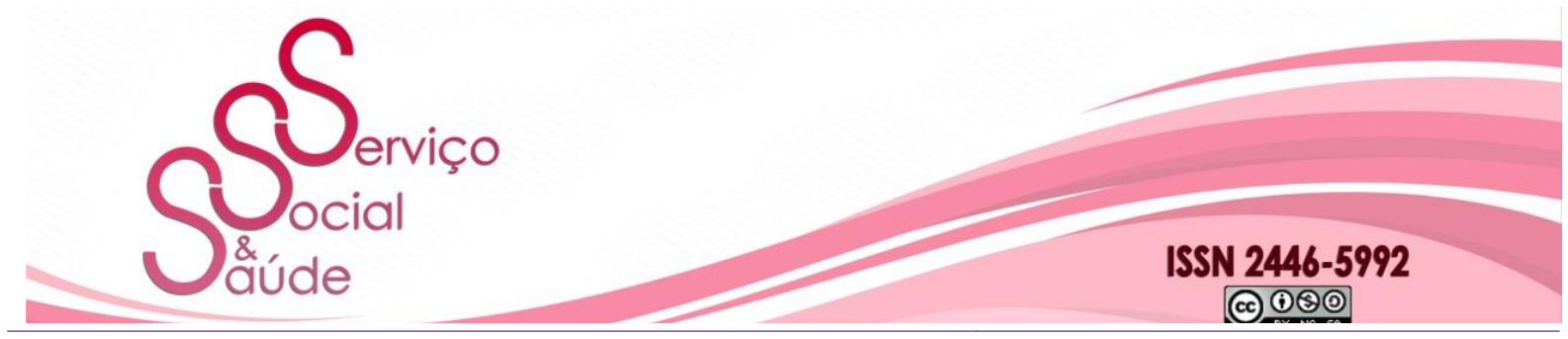

doi: $10.20396 /$ sss.v18i0.8656802

mais.

Do total de homicídios registrados em 2015 (59.080), 47,8\%, correspondem à juventude masculina, com idades entre 15 a 29 anos. Se considerados apenas os jovens do sexo masculino, com idades entre 15 e 19 anos, essa taxa atinge a marca de 53,8\%.

O Atlas de 2018 traz que, em 2016, o Brasil registou a marca de 62.517 homicídios, com base nas informações do Ministério da Saúde. Equivalente à taxa de 30,3 mortes para cada grupo de 100 mil pessoas. Na comparação, 30 vezes a taxa da Europa.

A taxa de homicídios de sujeitos não negros caiu $6,8 \%$, enquanto para a população negra, aumentou em 23,1\%; portanto, $71,5 \%$ das pessoas assassinadas, a cada ano, no Brasil, são pretas ou pardas.

Em 2016, foram assassinados 33.590 jovens com idades entre 15 e 29 anos e a maioria, 96,4\%, do sexo masculino. A taxa média do Brasil é de 65,5 jovens assassinados por grupo de 100 mil. Porém, as taxas variam em cada unidade federativa, com 19 em São Paulo e de 142,7, no Sergipe, por 100 mil habitantes. Das 27 unidades federativas, 20 registraram aumento do assassinato de jovens, em especial, Acre (+ 84,8\%) e Amapá (+ 41,2\%), seguidos de Rio de Janeiro, Bahia, Sergipe, Rio Grande do Norte e Roraima, com aumento aproximado de $20 \%$. As outras sete unidades registraram queda entre 13,5\% e 15,6\%, como Paraíba, Espírito Santo, Ceará e São Paulo.

O Atlas de 2019 traz que 35.783 jovens foram assassinados no Brasil, em 2017, representando, para cada 100 mil jovens, a taxa de 69,9 homicídios. De 2016 para 2017, o aumento da taxa foi de 6,7\%. Os estados com as menores taxas foram São Paulo, com 18,5; Santa Catarina, 30,2; e Piauí, 38,9. As maiores taxas foram registradas no Rio Grande do Norte, com 152,3; Ceará, 140,2; e em Pernambuco, 133,0.

Ao analisar as legislações, os dados estatísticos e a realidade social, identifica-se um cenário de "guerra social", permeado pela banalização da vida e potencialização desses homicídios, principalmente, por meio das ações do Estado em flexibilizar o acesso às armas, na atualidade. Uma "guerra social" estimulada pelo Estado e confirmada no cotidiano. Esse

\begin{tabular}{|l|c|c|c|c|c|c|c|c|}
\hline Serv. Soc. \& Saúde & \multicolumn{2}{|c|}{ Campinas, SP } & \multicolumn{2}{c|}{ v. 18} & $1-22$ & e019001 & 2019 & e-ISSN 2446-5992 \\
\hline Serv. Soc. \& Saúde & Campinas, SP & v. 18 & \multicolumn{1}{|c|}{$1-22$} & e019001 & 2019 & e-ISSN 2446-5992 \\
\hline Serv. Soc. \& Saúde & Campinas, SP & v. 18 & n. $1[27]$ & p.9-30 & jan./jun. 2019 & e-ISSN 2446-5992 \\
\hline
\end{tabular}




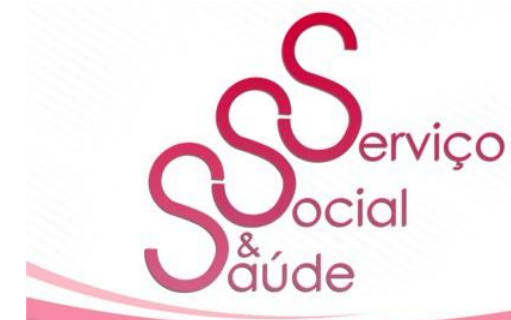

ISSN 2446-5992

(๑) $\odot \odot$

doi: $10.20396 /$ sss.v18i0.8656802

11

contexto, por ser contraditório, apresenta várias visões e divisões ideológicas, inclusive por considerarmos que a morte de jovens expressa uma determinada condição humana. Para Batista (2012, p.3-4), “O Estado agencia o extermínio cotidiano e a intelligentzia trata de mascará-lo. As operações letais de alta intensidade (como os dezenove mortos num só dia no morro do Alemão) não precisam mais ter sentido técnico, de resultados: o sucesso é o enfretamento em si”.

A morte de jovens negros/as, pobres e periféricos/as não sensibiliza significativa parte da sociedade. É como se a morte desses/as jovens - concreta ou simbólica - resolvesse o problema da criminalidade. Ademais, essa realidade requer um zoom para desvelar o que há por trás desses/as jovens que matam ou morrem. Nessa relação, é necessário aprofundar o debate sobre o "extermínio" dessas juventudes que, ora acontece por meio dos homicídios, ora por meio da morte psicossocial, visto que, mesmo em vida, os/as jovens não têm seus desejos reconhecidos e/ou são desrespeitados e seus direitos sociais negados e/ou violados. Isto é, há várias formas de "extermínio". Devemos, também, partir do princípio do humano genérico e reconhecer, verdadeiramente, a sua dinâmica. "Por isso, refletir sobre a questão do negro não é algo particular que só deve interessar às pessoas que pertencem a esse grupo étnico-racial ou aos militantes do Movimento Negro. É uma questão da sociedade brasileira e também da humanidade" (MUNANGA; GOMES, 2006, p. 178).

Quando se responsabiliza unicamente a desigualdade social pela criminalidade no País, cria-se a ideia de que pobreza e violência são palavras sinônimas, entretanto:

Em outras palavras, pobreza e desigualdade são e não são condicionantes da criminalidade, dependendo do tipo de crime, do contexto intersubjetivo e do horizonte cultural a que nos referirmos. Esse quadro complexo exige políticas sensíveis às várias dimensões que o compõem. É tempo de aposentar as visões unilaterais e o voluntarismo (SOARES, 2006, p. 94).

${ }^{6}$ Vide Batista (2012); Nascimento (2017); e Kon et al. (2017).

\begin{tabular}{|l|c|c|c|c|c|c|c|c|}
\hline Serv. Soc. \& Saúde & Campinas, SP & v. 18 & $1-22$ & e019001 & 2019 & e-ISSN 2446-5992 \\
\hline Serv. Soc. \& Saúde & Campinas, SP & v. 18 & \multicolumn{1}{|c|}{$1-22$} & e019001 & 2019 & e-ISSN 2446-5992 \\
\hline Serv. Soc. \& Saúde & Campinas, SP & v. 18 & n. $1[27]$ & p.9-30 & jan./jun. 2019 & e-ISSN 2446-5992 \\
\hline
\end{tabular}




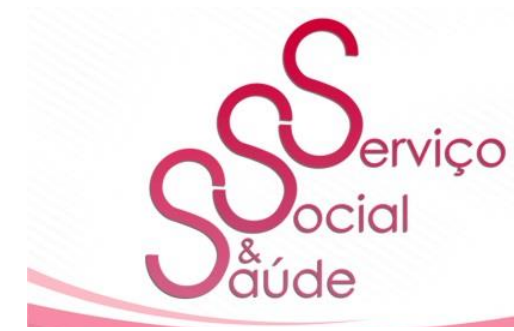

JOVENS NA MÍDIA
ISSN 2446-5992

(1) (1) (-)

doi: 10.20396/sss.v18i0.8656802

Trata-se de um aspecto complexo, o modo como as juventudes são apresentadas pela mídia, em determinadas situações. Porém, essas apresentações nos permitem refletir e apreender questões transversais e tangenciais que as envolvem, como é o caso do preconceito, da justiça por meio da vingança e da vingança por meio da justiça. Percebemos que parte significativa da mídia contribui para isso, além de produzir a massificação popular por meio da distorção e superficialidade da apresentação de determinados fatos que, consequentemente, aumentam os índices de audiência e se transformam na espetacularização da violência.

Ou seja, a divulgação midiática, amparada em dados quantitativos, nem sempre é suficiente quando o objetivo é explicar as causas da violência social ou decifrar as motivações humanas, intersubjetivas e socioculturais, mais as pulsões propriamente individuais aí envolvidas (SALES, 2007, p. 29).

Certamente, como pondera Soares (2011, p. 60-61), “[...] a mídia tem uma importância muito grande na definição dos temas que merecerão a atenção de todos, quando não na própria linha de pensamento que predominará em cada caso".

Percebe-se, então, que o assunto midiático e a ideologia norteadora são elementos que corroboram para a construção social daquilo que se acredita ser o outro. Isto é, na sociedade, vários/as jovens são vistos/as como sujeitos "criminosos", "violentos" (SOARES, 2011), e acabam por ser submetidos/as à punição mais cruel e imediata possível, como a morte para quem matou ou para quem é considerado/a suspeito/a de cometer crimes; modalidade de sentença pública que transfere para as pessoas os problemas que são da sociedade, e com abrangência muito mais ampla.

Nessa perspectiva, outra modalidade de sentença é a lógica da seletividade penal, constituída, significativamente, pelo público jovem, quer seja masculino ou feminino. As imagens transmitidas pela televisão e/ou pelas redes sociais sobre o que se chamam rebeliões não demonstram as raízes e nem os processos desumanos em que muitos/as se encontram, bem como os contextos, os modos de vida na prisão e a situação de quem é egresso/a do sistema prisional.

É importante refletir que o tempo passa de um modo diferente para quem foi

\begin{tabular}{|l|c|c|c|c|c|c|c|c|}
\hline Serv. Soc. \& Saúde & Campinas, SP & \multicolumn{2}{|c|}{ v. 18} & $1-22$ & e019001 & 2019 & e-ISSN 2446-5992 \\
\hline Serv. Soc. \& Saúde & Campinas, SP & v. 18 & \multicolumn{1}{|c|}{1 -22 } & e019001 & 2019 & e-ISSN 2446-5992 \\
\hline Serv. Soc. \& Saúde & Campinas, SP & v. 18 & n. $1[27]$ & p.9-30 & jan./jun. 2019 & e-ISSN 2446-5992 \\
\hline
\end{tabular}




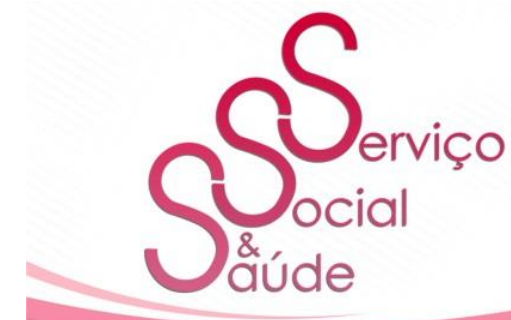

ISSN 2446-5992

(๑) $\odot$ (-)

doi: $10.20396 /$ sss.v18i0.8656802

13

condenado/a. A contagem do tempo e a matemática, também. O sujeito é afixado em sua condenação. Característica evidenciada nas vezes em que algum/alguma jovem usufruiu do direito à saída temporária, principalmente no dia das mães e dos pais. Soares (2011, p. 63-64) considera que:

[...] quem cometeu o crime é pregado na cruz de se mal feito, impossibilitando-se, assim, de mover-se, livrar-se desse "eu" que praticou o crime ou a violência. Por mais que o culpado pelo ato criminoso deixe de se identificar com esse "eu", a sociedade acusadora força-o a mirar-se nele. O rótulo que a sociedade prende em seu pescoço - "o criminoso", "o violento" - resiste às mudanças que o sujeito se esforça por empreender, caso tente se libertar da violência e de seu passado.

A intenção aqui não é realizar um julgamento moral. O objetivo é refletir sobre quanto o debate acerca da violência requer um olhar crítico que supere a abordagem simplista que alcança apenas a superficialidade dos fatos, ou seja, "Por favor, não me entendam mal. Não estou elogiando a violência nem mesmo a justificando. Não pretendo defender a agressão. Desejo apenas compreendê-la. Não há como mudar uma realidade se não a compreendermos" (SOARES et al., 2005, p. 216).

Essas reflexões nos auxiliam a entender que a violência não é a mesma para todos/as e que não é específica de determinada classe social, mas, nem sempre, a violência, tem o mesmo tratamento do poder público, da mídia e da sociedade. Isso depende das tramas em que a violência está inserida e constituída.

Os fatos midiáticos equivocados, certamente, alimentam o entendimento falseado da situação, impedem o conhecimento do todo e acabam por responsabilizar apenas uma parte. Por isso, é importante analisarmos como a violência se manifesta na sociedade mediante as diversas expressões da questão social e dos conflitos emergentes das relações sociais os quais são construídos e construtores, também de múltiplas violências.

A violência enquanto ato, é produto. Enquanto, constituição, é relacional e significativa. Assim, esses/as jovens acabam se tornando "monstros", "modelos de jovens perigosos/as" a serem eternizados/as na história e recordados/as em situações semelhantes,

\begin{tabular}{|l|c|c|c|c|c|c|c|c|}
\hline Serv. Soc. \& Saúde & Campinas, SP & v. 18 & $1-22$ & e019001 & 2019 & e-ISSN 2446-5992 \\
\hline Serv. Soc. \& Saúde & Campinas, SP & v. 18 & \multicolumn{1}{|c|}{$1-22$} & e019001 & 2019 & e-ISSN 2446-5992 \\
\hline Serv. Soc. \& Saúde & Campinas, SP & v. 18 & n. $1[27]$ & p.9-30 & jan./jun. 2019 & e-ISSN 2446-5992 \\
\hline
\end{tabular}




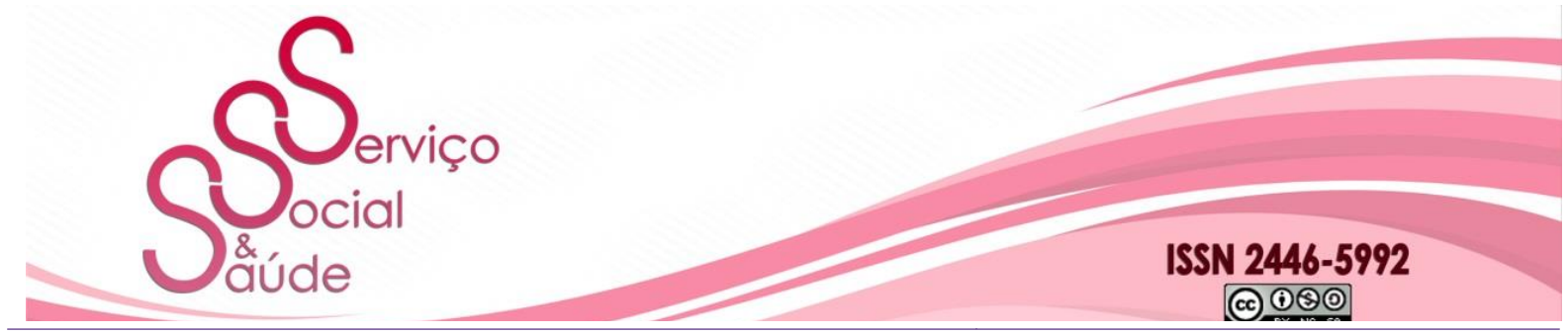

doi: $10.20396 /$ sss.v18i0.8656802

como referência moral de possíveis julgamentos de outros/as jovens que cometerem as mesmas ações. Esses processos de estigmatização, que rotulam o outro por suas ações, seu passado, que perdura como marcas subjetiva, moral e social, produzem invisibilidade (SOARES et al., 2005; 2011). Ao analisar os processos de invisibilização, nota-se que o sentimento de vingança corrobora para o olhar associativo do outro como metáfora da violência (SALES, 2007).

\section{A PRÁTICA INFRACIONAL COMO UM MODO DE VIDA?}

É importante também refletir sobre as adolescências/juventudes em contextos de práticas infracionais e aqueles/as que estão em cumprimento de medidas socioeducativas em meio aberto (Prestação de Serviço à Comunidade e Liberdade Assistida) ou fechado (Semiliberdade e Internação). A intenção não é julgar e nem defender a prática infracional, o crime e a criminalidade, e sim analisar como os/as jovens têm encontrado sentido em suas vidas, nesses contextos. E como os atos infracionais perpassam as suas trajetórias. Só é possível avançar nesse debate a partir do momento em que atentarmos para a condição de vida e para as peculiaridades desse sujeito que, de algum modo, precisa se afirmar no "mundo".

Se o crime não compensa, por que muitos/as jovens são recrutados/as diariamente para o "mundo do crime"? Questão interessante para pensarmos os benefícios e riscos que a criminalidade oferece às juventudes. Para isso, é adequado compreender o papel, a relação e o sentido que os/as jovens estabelecem com aquilo que pensamos sobre violência e criminalidade (SOARES, 2011).

Nessa lógica, relataremos sucintamente três casos de adolescentes que foram atendidos em uma Unidade Socioeducativa de Internação, por protagonizarem trajetória em atos infracionais desde a infância. Esses sujeitos receberam a medida de internação, mediante processo legal, por terem cometido algum ato infracional, considerado pelo juiz, cabível de aplicação da medida de internação, conforme as especificações do Estatuto da Criança e do Adolescente (ECA). Por questões éticas, preservamos o nome da instituição e utilizamos nomes fictícios para nos referirmos aos sujeitos citados.

\begin{tabular}{|l|c|c|c|c|c|c|c|}
\hline Serv. Soc. \& Saúde & Campinas, SP & v. 18 & $1-22$ & e019001 & 2019 & e-ISSN 2446-5992 \\
\hline Serv. Soc. \& Saúde & Campinas, SP & v. 18 & $1-22$ & e019001 & 2019 & e-ISSN 2446-5992 \\
\hline Serv. Soc. \& Saúde & Campinas, SP & v. 18 & n. $1[27]$ & p.9-30 & jan./jun. 2019 & e-ISSN 2446-5992 \\
\hline
\end{tabular}




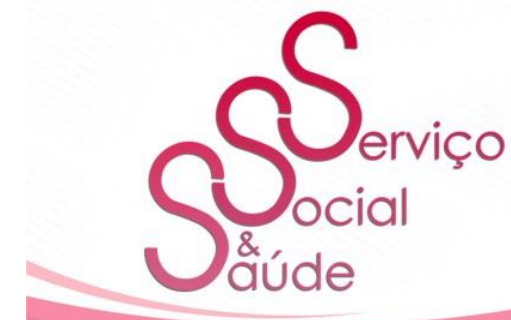

ISSN 2446-5992

(c) 18 (3)

doi: $10.20396 /$ sss.v18i0.8656802

15

No primeiro caso, apresenta-se João, de 12 anos de idade, que residia em um barraco de madeira de um cômodo, construído às margens de um córrego. Na infância, iniciou a sua trajetória de vida nas ruas, fazendo uso de drogas e praticando atos infracionais. Foi apreendido por ter praticado furto. Em seu primeiro ato, após completar 12 anos de idade, recebeu a medida socioeducativa de internação.

No segundo caso, Jorge, de 12 anos de idade, envolvido com o tráfico de drogas, furtos, assaltos e homicídios, desde a infância. Ele recebeu outras medidas socioeducativas em meio aberto, até que passou por medida restritiva de liberdade (internação). Mesmo com pouca idade e baixa estatura, conseguia exercer liderança sobre alguns adolescentes da instituição. Percebia-se que seu envolvimento com as práticas infracionais era contínuo e intenso.

No terceiro caso, José, de 15 anos de idade, que residia com sua família numa comunidade, estava envolvido com furtos e tráfico de drogas em sua região. Passou por outras medidas socioeducativas em meio aberto até chegar à internação, de onde se evadiu uma vez, numa atividade externa. Após alguns dias, José foi apreendido pela polícia. Ao ser entrevistado por uma repórter, afirmou: "Eu já cometi mais de 500 atos infracionais". A reportagem ganhou destaque no telejornal. José ganhou status de "periculoso" e aproveitou o momento para chocar, ao mostrar que "representava o crime", "que tinha disposição": o que não era bem assim! José não era o que indicava ser. Ao participar de uma oficina de rap e poesia, compôs os seguintes versos:

Então, pode crer, vou abrir o meu coração/ Nasci pra ser feliz e não pra ser ladrão/ Viver na humildade e com dignidade/ Viver pelo amor e não pela maldade/ Lembra? Você não nasceu pronto/ A sociedade que fabrica o monstro/ Então, o ECA é necessário e importante/ Ele não foi feito para ficar na estante/.

A letra de rap escrita por ele é significativa. Fala do objetivo de sua existência, que é "ser feliz". Apresenta seus valores: "humildade", "dignidade" e "amor". Interpela o seu interlocutor, lembrando-o de que ele não "nasceu pronto", como também salienta Cortella (2008). Na sequência, José afirma que "a sociedade que fabrica o monstro". Isto é, ele olha

\begin{tabular}{|l|c|c|c|c|c|c|c|c|}
\hline Serv. Soc. \& Saúde & Campinas, SP & v. 18 & $1-22$ & e019001 & 2019 & e-ISSN 2446-5992 \\
\hline Serv. Soc. \& Saúde & Campinas, SP & v. 18 & \multicolumn{1}{|c|}{$1-22$} & e019001 & 2019 & e-ISSN 2446-5992 \\
\hline Serv. Soc. \& Saúde & Campinas, SP & v. 18 & n. $1[27]$ & p.9-30 & jan./jun. 2019 & e-ISSN 2446-5992 \\
\hline
\end{tabular}




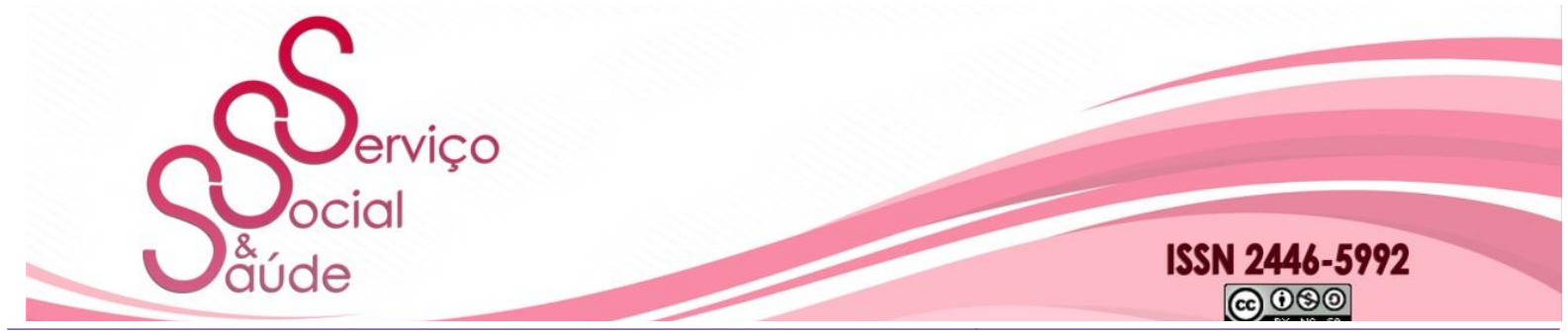

doi: $10.20396 /$ sss.v18i0.8656802

para além de si, fala da sociedade em que muitos jovens, iguais a ele, são negligenciados.

Não desconsideramos a responsabilidade do jovem sobre as suas escolhas e práticas, mas responsabilizá-lo por aquilo que não tem culpa e sem analisar contextos: é altamente perverso, inclusive, quando se exige do jovem algo que não lhe foi oportunizado.

Outro aspecto importante a ser considerado é a busca dos jovens pelo reconhecimento. $\mathrm{O}$ ato infracional, para eles, pode ser um meio de fugir da invisibilidade, mesmo, às vezes, reforçando-a. Esse movimento acaba por definir o caminho que trilha. Somente uma análise sensível é capaz de perceber que: "Quando não se é visto e se vê, o mundo oferece o horizonte, mas furta a presença, aquela presença verdadeira que depende da interação, da troca, do reconhecimento, da relação humana" (SOARES et al., 2005, p. 167).

O que sobressai em comum nesses breves relatos de casos é que a prática do ato infracional caracteriza a trajetória de vida desses jovens, e que esses atos representam, de certo modo, uma forma de romper a invisibilidade social, porém com sentidos diferentes.

João furtava som de carro para trocar por objetos de valor econômico bem inferior, como alimentação e drogas. João, por algumas visões, era a "sementinha do mal", mas era explorado pelos adultos de sua comunidade devido à sua coragem e inocência. Por ter baixa estatura, não causava desconfiança e com suas mãos pequenas apresentava muita habilidade para retirar o som dos painéis dos carros. Para ele, os furtos não eram atos infracionais e sim uma forma de conseguir o que queria, de sobreviver.

Jorge era um adolescente sedutor, sabia conversar tranquilamente, bem como falar de modo autoritário e violento. Ele dizia ser do crime. Naquele contexto, não vislumbrava outra condição de vida a não ser retornar para o grupo de jovens ao qual era vinculado, para comentar atos infracionais.

José tinha facilidade para expressar seus sentimentos. Ele sabia que não poderia perder a oportunidade de mostra-se grande para a mídia, mesmo dizendo coisas que não fez. Nas oficinas de rap e poesia, o jovem se sentia à vontade para expressar suas ideias e dialogar sobre os sentidos de seus atos infracionais: "Então, pode crer, vou abrir o meu coração".

\begin{tabular}{|l|c|c|c|c|c|c|c|c|}
\hline Serv. Soc. \& Saúde & Campinas, SP & v. 18 & $1-22$ & e019001 & 2019 & e-ISSN 2446-5992 \\
\hline Serv. Soc. \& Saúde & Campinas, SP & v. 18 & \multicolumn{1}{|c|}{$1-22$} & e019001 & 2019 & e-ISSN 2446-5992 \\
\hline Serv. Soc. \& Saúde & Campinas, SP & v. 18 & n. $1[27]$ & p.9-30 & jan./jun. 2019 & e-ISSN 2446-5992 \\
\hline
\end{tabular}




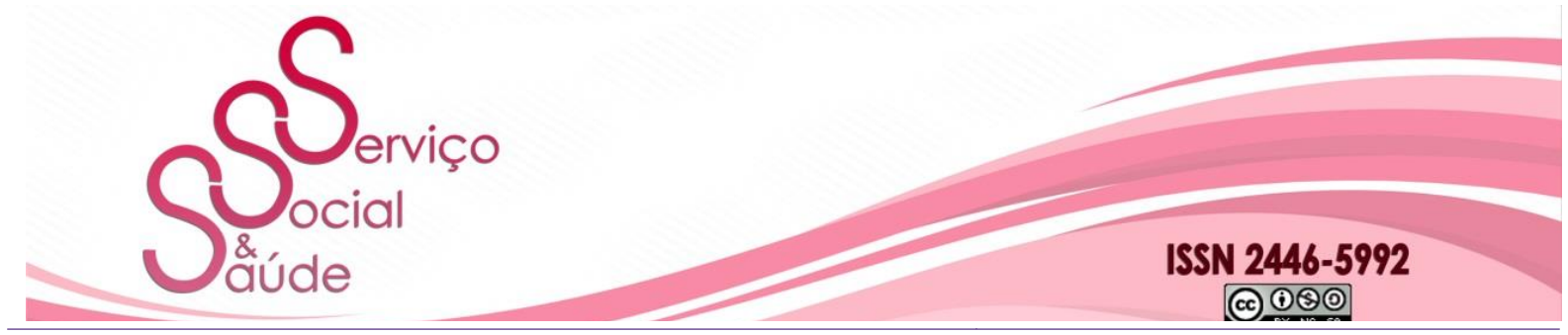

doi: $10.20396 /$ sss.v18i0.8656802

Coração marcado por conflitos familiares, questionamentos e esperanças.

Enfim, Jorge e José tinham envolvimentos mais efetivos com as práticas infracionais, considerando as suas peculiaridades. Não sabemos, entretanto, se, nos dias de hoje, esses jovens estão vivos...

\section{CONSIDERAÇÕES FINAIS}

O debate sobre juventudes, violência e invisibilidade é inesgotável. Na atualidade, os/as jovens têm muito a dizer, mas nem sempre o fazem por meio do discurso que queremos, pois utilizam outros recursos, outras linguagens, principalmente as juventudes periféricas. Seja no baile funk, nas ocupações de escolas, nos "rolezinhos" em shoppings, praças e parques, no consumismo, os/as jovens estão dizendo que querem alguma coisa e desejam fazer algo.

As juventudes não estão perdidas e tampouco vivem sem sonhos. Caso contrário, não lutariam contra a invisibilidade que, socialmente, lhes é atribuída. Considerando a particularidade e o reconhecimento dessa luta, é preciso ouvir e pensar as suas expressões culturais, políticas, artísticas, bem como suas linguagens, principalmente, o silêncio, que, por ser também linguagem, é revelador. Assim, é preciso ter sensibilidade para entender o que esse silêncio quer dizer: são dúvidas, certezas, receios, ansiedades, prazeres, vazios. Enfim, para cada jovem, uma interpretação.

Se não entendemos as juventudes, suas diferenças e indiferenças, reproduzimos o olhar opaco da massa societária que tem o dom para julgar, tipificar e excluir o diferente, o outro. Assim, os processos da formação da violência e da criminalização aprofundam-se com a judicialização dos conflitos que poderiam ser resolvidos antes, e de outra forma.

Já a invisibilidade afeta diretamente a construção da identidade dos/as jovens, por meio do preconceito, racismo e estigma. Este último "[...] dissolve a identidade do outro e a substitui pelo retrato estereotipado e a classificação que lhe impomos" (SOARES et al., 2005, p.175). Isto é, imposição muito frequente daqueles que são favoráveis à redução da idade de

\begin{tabular}{|l|c|c|c|c|c|c|c|}
\hline Serv. Soc. \& Saúde & Campinas, SP & \multicolumn{2}{|c|}{ v. 18} & $1-22$ & e019001 & 2019 & e-ISSN 2446-5992 \\
\hline Serv. Soc. \& Saúde & Campinas, SP & v. 18 & \multicolumn{1}{|c|}{$1-22$} & e019001 & 2019 & e-ISSN 2446-5992 \\
\hline Serv. Soc. \& Saúde & Campinas, SP & v. 18 & n. $1[27]$ & p.9-30 & jan./jun. 2019 & e-ISSN 2446-5992 \\
\hline
\end{tabular}




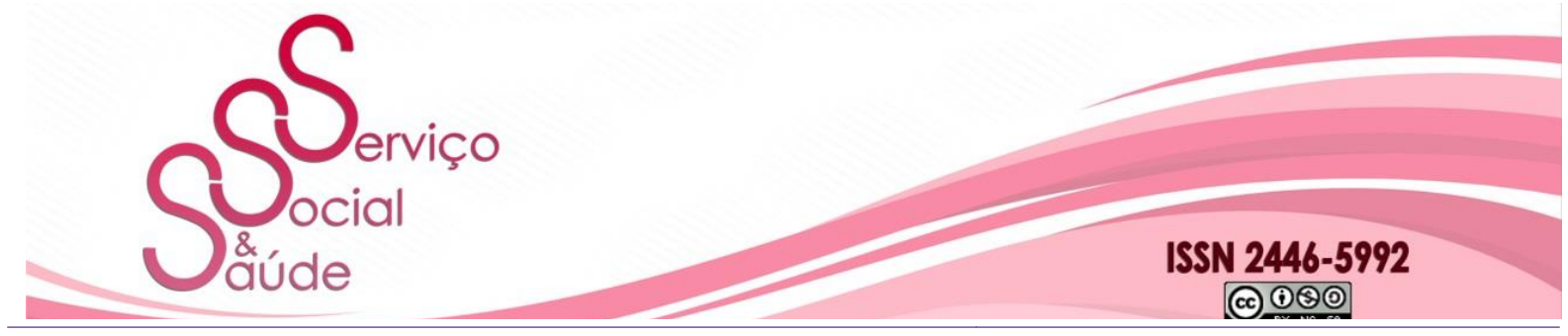

doi: $10.20396 /$ sss.v18i0.8656802

18

imputabilidade penal; dos que são favoráveis ao trabalho infantil; dos que aprovam ações de tortura contra os/as jovens; pois entendem que assim é que, de fato, a pessoa se tornará alguém, ou, até mesmo, alguém morto.

A luta contra a invisibilidade é cotidiana. E uma das formas de confrontá-la está na arte, como se identifica nas reflexões de Soares et al. (2005), que cita a cultura hip-hop como uma alternativa. E Lacaz et al.(2015) que veem a arte como potência e forma de resistência aos processos de marginalização aos quais muitos/as jovens são submetidos/as.

Verifica-se, a partir desses apontamentos, que um caminho a ser considerado é a proposta de modalidades artísticas que possibilitem a leitura da realidade, a expressão de sentimentos, a produção de conhecimento voltado para a coletividade, para promover reflexões e a educação política dos sujeitos. Trata-se da arte na perspectiva crítica, que, nessa lógica, “[...] educa o homem fazendo-o transcender a fragmentação produzida pelo fetichismo da sociedade mercantil" (FREDERICO, 2013, p. 135).

Assim, a arte torna-se a "arma" para a construção de um caminho diferente para proporcionar comunicação saudável e para que os/as jovens sejam tratados/as com dignidade, qualquer que seja a posição que ocupem nas relações de conflito ou violência.

A luta pela efetivação dos direitos é outro caminho proposto, não somente pelos direitos. A diferença está em saber agir, no como fazer, na construção coletiva, nas estratégias, a partir do entendimento dos processos políticos, jurídicos e sociais que constituem a área do direito. Em diversos contextos, o direito só consolida-se quando é reivindicado e sua possível efetivação se faz, principalmente, na luta. São aspectos importantes para que as juventudes tenham condições reais de satisfazer e produzir as suas necessidades e seus desejos. Mas é preciso investimento do poder público; a oferta de serviços com profissionais qualificados e bem remunerados; a articulação entre as políticas públicas; e a consolidação, expansão e divulgação do Sistema de Garantia de Direitos (BAPTISTA, 2012). Considerando, ademais, conforme Fávero et al. (2015), a necessidade de reavaliar a distribuição e a articulação dos serviços - seja das políticas sociais ou do judiciário -, de acordo com a realidade de cada território.

\begin{tabular}{|l|c|c|c|c|c|c|c|c|}
\hline Serv. Soc. \& Saúde & Campinas, SP & v. 18 & $1-22$ & e019001 & 2019 & e-ISSN 2446-5992 \\
\hline Serv. Soc. \& Saúde & Campinas, SP & v. 18 & \multicolumn{1}{|c|}{$1-22$} & e019001 & 2019 & e-ISSN 2446-5992 \\
\hline Serv. Soc. \& Saúde & Campinas, SP & v. 18 & n. $1[27]$ & p.9-30 & jan./jun. 2019 & e-ISSN 2446-5992 \\
\hline
\end{tabular}




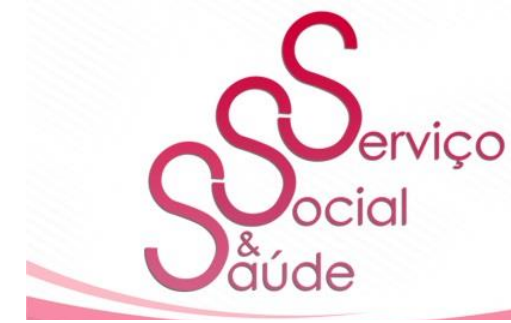

ISSN 2446-5992

(c) 10 (-)

doi: $10.20396 /$ sss.v18i0.8656802

19

Enfim, comumente, a violência é associada às responsabilidades das políticas de segurança pública, que têm a sua importância, mas o problema surge quando é apresentada de maneira punitivista, isolada, rígida e pela via da "ordem", para que ocorra o "progresso".

Recebido em junho de 2018 - Aprovado em maio de 2019

\section{REFERÊNCIAS}

ABRAMO, H. W.; BRANCO, P. P. M. (Orgs.). Retratos da juventude brasileira: análises de uma pesquisa nacional. São Paulo: Fundação Perseu, 2005.

ADORNO, S.; NERY, M. B. Crime e violência em São Paulo: retrospectiva teóricometodológica, avanços, limites e perspectivas futuras. Caderno Metrópole. Rev. 21, n. 44, São Paulo, jan./abr. 2019. p. 169-194. Epub apr ,15, 2019. Disponível em: http://dx.doi.org/10.1590/2236-9996.2019-4408. Acesso em: 3 ago. 2019.

BAPTISTA, M. V. Algumas reflexões sobre o sistema de garantia de direitos. Serviço Social \& Sociedade, Sociedade Civil e Controle Social, n. 109, jan./fev. 2012. p. 179-199. Disponível em: http://dx.doi.org/10.1590/S0101-66282012000100010. Acesso em: 12 dez. 2018.

BATISTA, V. M. Adesão subjetiva à barbárie. In: BATISTA, V. M. (Org.). Loïc Wacquant e a questão penal no capitalismo neoliberal. 2. ed. Rio de Janeiro: Revan, 2012.

BRASIL. Lei n. 8.069, de 13 de julho de 1990. Dispõe sobre o Estatuto da Criança e do Adolescente e dá outras providências. Diário Oficial da União, Brasília,16 jul. 1990.

BRASIL. Lei n. 10.826, de 22 de dezembro de 2003. Dispõe sobre o registro, a posse e comercialização de armas de fogo e munição [Estatuto do Desarmamento]. Diário Oficial da União, Brasília, 22 dez. 2003.

BRASIL. Lei n. 12.852, de 5 de agosto de 2013. Institui o Estatuto da Juventude e dispõe sobre os direitos dos jovens, os princípios e as diretrizes das políticas públicas de juventude e o Sistema Nacional de Juventude (Sinajuve). Diário Oficial da União, Brasília. 6 ago. 2013.

CORTELLA, M. S. Não nascemos prontos. 6. ed. São Paulo: Vozes, 2008.

\begin{tabular}{l|c|c|c|c|c|c|c|}
\hline Serv. Soc. \& Saúde & Campinas, SP & \multicolumn{1}{|c|}{ v. 18} & $1-22$ & e019001 & 2019 & e-ISSN 2446-5992 \\
\hline Serv. Soc. \& Saúde & Campinas, SP & v. 18 & $1-22$ & e019001 & 2019 & e-ISSN 2446-5992 \\
\hline Serv. Soc. \& Saúde & Campinas, SP & v. 18 & n. $1[27]$ & p.9-30 & jan./jun. 2019 & e-ISSN 2446-5992 \\
\hline
\end{tabular}




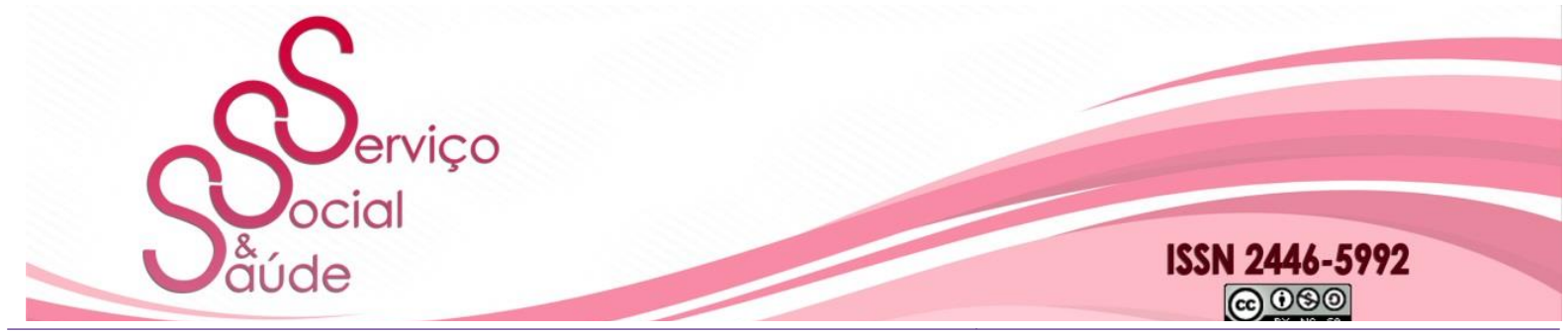

doi: $10.20396 /$ sss.v18i0.8656802

CHAUI, M. de S. Sobre a violência. Belo Horizonte: Autêntica, 2017.

CHIZZOTTI, A. Pesquisa em Ciências Humanas e Sociais. 11. ed. São Paulo: Cortez, 2010. DECLARAÇÃO Universal dos Direitos Humanos. Assembleia Geral das Nações Unidas. Resolução 217 A III, 10 dez. 1948. Disponível em: https://www.unicef.org/brazil/declaracaouniversal-dos-direitos-humanos. Acesso em: 1ํo ago. 2019.

FÁVERO, E.; DIAS, J. A.; RAPHAEL, S. L. M.; SANTOS, V. S. N. dos. A dimensão socioterritorial na interface entre a Justiça da Infância e Juventude e a Assistência Social em São Paulo. Serviço Social \& Saúde, 13(2), 2015, p. 169-187. Disponível em: https://doi.org/10.20396/sss.v13i2.8634899. Acesso em: 4 ago. 2019.

FREDERICO, C. A arte no mundo dos homens: o itinerário de Lukács. São Paulo: Expressão Popular, 2013.

GOMES, N. L.; LABORNE, A. A. de P. Pedagogia da crueldade: racismo e extermínio da juventude negra. Educação em Revista, v. 34, Belo Horizonte, 2018, Epub 23, nov. 2018. p. 1-26. Disponível em: http://dx.doi.org/10.1590/0102-4698197406. Acesso em: 5 ago. 2019.

INSTITUTO DE PESQUISA ECONÔMICA APLICADA; FÓRUM BRASILEIRO DE SEGURANÇA PÚBLICA (Orgs.). Atlas da violência 2017. Rio de Janeiro: Ipea; FBSP, 2017.

INSTITUTO DE PESQUISA ECONÔMICA APLICADA; FÓRUM BRASILEIRO DE SEGURANÇA PÚBLICA (Orgs.). Atlas da violência 2018. Rio de Janeiro: IPEA; FBSP, 2018.

INSTITUTO DE PESQUISA ECONÔMICA APLICADA; FÓRUM BRASILEIRO DE SEGURANÇA PÚBLICA (Orgs.). Atlas da violência 2019. Brasília; Rio de Janeiro; São Paulo: IPEA; FBSP, 2019.

KON, N. M.; ABUD, C. C.; SILVA, M. L. da. (Orgs.). O racismo e o negro no Brasil: questões para a psicanálise. São Paulo: Perspectiva, 2017.

LACAZ, A. S.; LIMA, S. M.; HECKERT, A. L. C. Juventudes periféricas: arte e resistências no contemporâneo. Psicologia Social. v. 27, n.1, Belo Horizonte, jan./abr. 2015. p. 58-67. Disponível em: http://dx.doi.org/10.1590/1807-03102015v27n1p058. Acesso em: 15 nov. 2018.

v. 18

v. 18

\begin{tabular}{l|l|l}
\multicolumn{1}{c|}{$1-22$} & $\mathrm{e} 01900$ \\
$1-22$ & $\mathrm{e} 019001$
\end{tabular}

2019 e-ISSN 2446-5992

Serv. Soc. \& Saúde

\begin{tabular}{|l|l|l|}
\hline v. 18 & n. 1 [27] & p.9-30
\end{tabular}

jan./jun. 2019 e-ISSN 2446-5992 


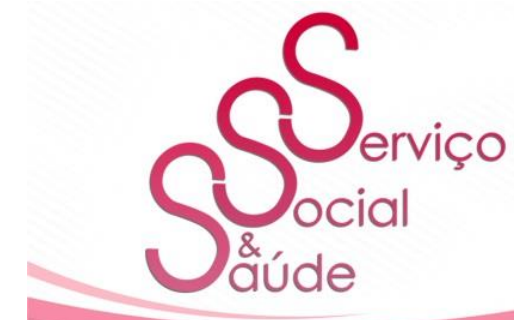

ISSN 2446-5992

(c) 18 (3)

doi: $10.20396 /$ sss.v18i0.8656802

MARX, KARL. Manuscritos econômico-filosóficos. São Paulo: Boitempo, 2004.

MUNANGA, K.; GOMES, N. L. O negro no Brasil de hoje. São Paulo: Global, 2006.

NASCIMENTO, A. O genocídio do negro brasileiro: processo de um racismo mascarado. 2. ed., São Paulo: Perspectiva, 2017.

NÚCLEO DE ESTUDOS DA VIOLÊNCIA (NEV-USP); WORLD HEALTH ORGANIZATION COLLABORATING CENTRE FOR RESEARCH ON VIOLENCE PREVENTION. Prevenindo a violência juvenil: um panorama das evidências. 2015.

SALES, M. A. (In)visibilidade perversa: adolescentes infratores como metáfora da violência. São Paulo: Cortez, 2007.

SOARES, L. E.; MV Bill; ATHAYDE, C. Cabeça de porco. Rio de Janeiro: Objetiva, 2005.

SOARES, L. E. Justiça: pensamento alto sobre violência, crime e castigo. Rio de Janeiro:

Nova Fronteira, 2011.

SOARES, L. E. Segurança pública: presente e futuro. Estudos Avançados. v.20, n.56, São Paulo, jan./abr. 2006. p. 91-106. Disponível em: http://dx.doi.org/10.1590/S010340142006000100008 Acesso em: 15 ago. 2019.

WAISELFISZ, J. J. Mapa da violência 2014: os jovens do Brasil. Brasília, 2014.

WAISELFISZ, J. J. Mapa da violência 2015: mortes matadas por armas de fogo. Brasília, 2015.

WAISElfiSZ, J. J. Mapa da violência 2016: homicídios por arma de fogo no Brasil. Brasília: Flacso Brasil, 2016. 


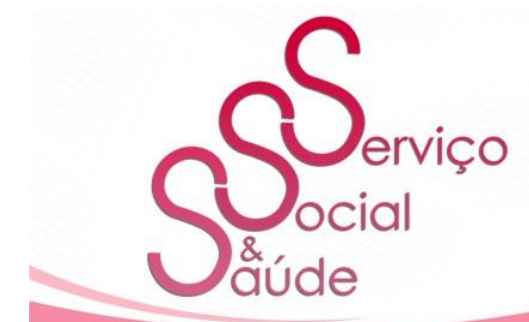

ISSN 2446-5992

(C) (1) (-)

doi: $10.20396 /$ sss.v18i0.8656802 